\title{
Case Report \\ POST-PARTUM UTERINE PROLAPSE IN A NON-DESCRIPT BUFFALO: CASE REPORT
}

\author{
ANIL M., RAJASHRI M. 'AND ANIL KUMAR REDDY K. \\ Department of Veterinary Gynaecology and Obstetrics P.V. Narsimha Rao Telangana Veterinary University, Rajendranagar, Hyderabad, 500030, Telangana \\ *Corresponding Author: Email-rsri0835@gmail.com
}

Received: January 31, 2018; Revised: February 05, 2018; Accepted: February 06, 2018; Published: February 15, 2018

\begin{abstract}
The present communication reports a case of uterine prolapse in a local non-descript buffalo and its successful reduction, replacement and repositioning.
Keywords: Uterine prolapse, Buffalo, epidural anaesthesia, Calcium borogluconate.

Citation: Anil M., et al., (2018) Post-Partum Uterine Prolapse in A Non-Descript Buffalo: Case Report. International Journal of Agriculture Sciences, ISSN: 0975-3710 \& E-ISSN: 0975-9107, Volume 10, Issue 3, pp.-5102-5103. DOl: http://dx.doi.org/10.9735/0975-3710.10.3.5102-5103
\end{abstract}

Copyright: Copyright@2018 Anil M., et al., This is an open-access article distributed under the terms of the Creative Commons Attribution License, which permits unrestricted use, distribution and reproduction in any medium, provided the original author and source are credited.

Academic Editor / Reviewer: Surabhi, Dr Soren Simson

\section{Introduction}

Prolapse or eversion of uterus is also called 'casting of weathers' or 'casting of calf bed [1]. Uterine prolapse is one of the most potentially dangerous complications associated with calving [2]. Post-partum prolapse of uterus through vulva is an obstetrical non-hereditary complication of third stage of labor, commonly observed in the cattle, buffalo and ewes, occasionally in sows and rare in bitches, queens and mares [3]. In most cases, it occurs immediately after parturition or occasionally up to several hours afterward and rare cases, it may occur 48 to 72 hours after parturition [4,5]. Samad et al. [6] reported an incidence of $11 \%$ for buffaloes affected with postpartum uterine prolapse. In ruminants, the uterine prolapse is generally a complete inversion of the gravid cornua with incidence 0.3 to $0.5 \%$ of all calvings [7]. The present study reports post partum uterine prolapse in a local non-descript buffalo.

\section{Case history and clinical examination}

A pleuriparous local buffalo aged about 6yrs was attended at the door step of a farmer with a history of parturition 18hrs before and placenta was expelled out. The calf was apparently healthy. Buffalo which was in sternal recumbency had severe tenesmus. The uterus was turned inside out exposing inner walls, cervix was edematous, inflamed and the maternal caruncles were covered by dirt, dust, soil and hanging up to the hocks. Clinical examination revealed rectal temperature of $100.5^{\circ} \mathrm{F}$, pale conjuctival mucous membrane, respiratory and pulse rates were slightly elevated.

\section{Treatment}

The prolapsed mass was washed gently with warm saline and then with $1 \%$ potassium parmanganate solution to remove the debris. To prevent straining during prolapsed organ replacement, $2 \%$ lignocaine $(5 \mathrm{ml})$ was given epidurally at first and second inter-coccygeal space. For easy repositioning, prolapsed mass was lifted above the level of ischial arch to drain out the urine. To reduce the size of prolapsed organ, ice- pack was applied. Then, with the help of finger tips and palm, the prolapsed mass was repositioned up to vagina. Finally, the prolapsed uterine mass was pushed gently by first through vagina, cervix and uterine body. To retain the uterus in place, purse string suture was placed in the vulva with sterile cotton thread. The animal was treated with fluid therapy, $5 \%$ DNS $-500 \mathrm{ml}$ and Calborol $450 \mathrm{ml} \mathrm{I/N}$, antibiotic (Inj. Enrofloxacin 5mg/kg b.wt), anti- inflammatory analgesic (Inj. Meloxicam $0.2 \mathrm{mg} / \mathrm{kg}$ b.wt) and antihistamineChlorphenaramine (Inj. Histanil-12ml).Antibiotic and analgesic therapy was given for 5 days.

\section{Discussion:}

The exact etiology of uterine prolapsed is still unclear, however hypocalcaemia [8], poor uterine tone, increased straining, conditions that increase the intra abdominal pressure including tympany, excessive estrogen content in the feed [2], forced traction of the foetus [5] are the contributing factors for the onset of the condition. Fubini and Ducharme, (2006) [9] reported that most of the animals suffering with uterine prolapse are hypocalcaemic. So, calcium borogluconate was given to prevent impending signs of hypocalcaemia. In the present study, caudal epidural anaesthesia was achieved before the replacement of a uterine prolapse to reduce straining and desensitization of the perineum which was in agreement to that of Kumar and Yasotha, (2015) [2]. Moreover, Scott and Gessert (1998) [10] reported that lignocaine $(0.5 \mathrm{mg} / \mathrm{kg}$ b.wt) will provide adequate analgesia to permit replacement of uterine prolapse after 5 to $10 \mathrm{~min}$.

Although, post-operative treatment with oxytocin was considered helpful in uterine tone restoration and subsequent prevention of reprolapse [5], preoperative treatment with oxytocin makes replacement more difficult [11]. Thus, oxytocin treatment was not attempted in the present comminique. Uterine prolapse is an emergency, which needs immediate proper treatment, otherwise interference in the blood supply of prolapsed mass may resulted into edema, cyanosis and later on may develop into gangrene [12]. Manure and dirt materials were removed carefully and potassium permanganate solution was used to prevent the uterine infection as reported by [13 \& 14]. Shock, hemorrhage and thromboembolism are potential sequelae of a prolonged prolapse [15]. Administration of broad spectrum antibiotic therapy was continued five days after replacement of the prolapsed mass which will prevent secondary bacterial infection [16].

\section{Conclusion}

Prompt treatment of uterine prolapse is essential to prevent toxaemia and death of the animal. The present case reports successful correction of uterine prolapse along with its management. 


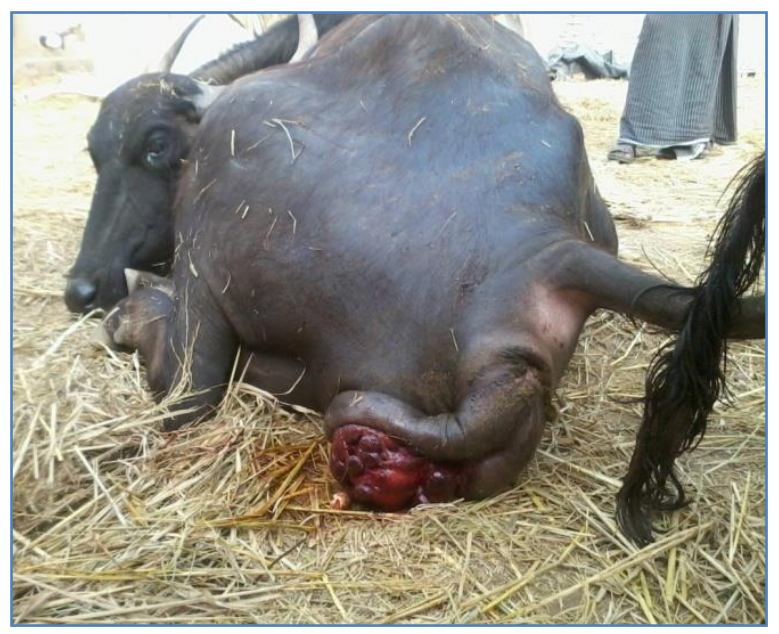

Fig-1 Non-descript buffalo affected with post-partum uterine prolapse

Application of research: The present case study reports the necessity for early recognition and treatment of the prolapsed mass which also prevents its recurrence at subsequent parturitions

Research Category: Veterinary Gynaecology and Obstetrics

Abbreviations: DNS: Dextrose Normal Saline

Acknowledgement / Funding: Author are thankful to Department of Veterinary Gynaecology and Obstetrics, P.V. Narsimha Rao Telangana Veterinary University, Rajendranagar, Hyderabad, Telangana, 500030

\section{*Principle Investigator: K. Anil Kumar Reddy}

University: P.V. Narsimha Rao Telangana Veterinary University, Rajendranagar, Hyderabad, Telangana, 500030

Research project name or number: NIL

Author Contributions: All author equally contributed.

Author statement: All authors read, reviewed, agree and approved the final manuscript

\section{Conflict of Interest: None declared}

Ethical approval: The present case report does not contain any studies with human participants or animals performed by any of the authors

\section{References}

[1] Sharma S. and Dhami A.J. (2007) Indian J. Field Vets., 3,14-15.

[2] Kumar S. A. and Yasotha A. (2015) Journal of Agriculture and Veterinary Science, 8(1), 14-16.

[3] Bhoi D.B and Parekar S.S. (2009) Veterinary World, 2(4), 149.

[4] Roberts S.J. (1971) Veterinary obstetrics and genital diseases, 2nd edn. C.B.S.Publisher and distributors, Delhi. pp. 308-313.

[5] Noakes E.D., Parkinson T.J. and England G.C.W. (2001) Arthur's Veterinary Reproduction \& Obstetrics. $8^{\text {th }}$ edition Published by Harcourt (India) Private Ltd., New Delhi.

[6] Samad A., Ali C.S., Rehman N.U., Ahmad A. and Ahmad N. (1987) Pak. Vet. J., 7, 16-19.

[7] Luktuke S. N and Chaudhary G. (1965) Indian Vet. J., 42, 930.

[8] Roberts S. J. (2004) Injuries and diseases of the puerperal period. In: Veterinary Obstetrics and Genital Diseases (Theriogenology). 2nd ed. CBS Publishers and Distributors, New Delhi, India, pp. 300-335.

[9] Fubini S.L. and Ducharme G.N. (2006) Surgical Conditions of the Post Partum Period. Text Book of Farm Animal Surgery, pp: 333-338.
[10] Scott P. and Gessert M. (1998) Practice, 20, 28-34

[11] Manfield G. (2006) Uterine prolapse in cattle. Control and Therapy Series: No. 29. Post Graduate Foundation, Level 2 Conference Centre, B22, University of Sydney, NSW, Australia.

[12] Kapadiya P.S., Chauhan P.M., Nakhashi H.C., Sharma V.K. and Sutaria T.V. (2015) J. Livestock Sci., 6, 109-112.

[13] Prakash S., Selvaraju M., Manokaran S., Ravikumar K. and Palanisamy M. (2016) Int. J. Sci. Environ. Technol., 5(4), 1952 - 1954.

[14] Hasan T., Azizunnesa, Parvez M.A., Paul P., Akter S., Faruk M.O. and Hossain D. (2017) Res. J. Vet. Pract., 5(1), 1-4.

[15] Pothiappan P., Sureshkumar R., Vijayakumar H. and Rao. G. (2013) Indian Vet. J., November, 90 (11), 67 - 68

[16] Borobia- Belsue J. (2006) Vet. Rec., pp: 380. 